\title{
Kajian Rupabheda: Tokoh-tokoh Sri Tanjung pada Relief Candi Penataran
}

\author{
Wegig Murwonugroho, Miftakhuddin \\ Magister Desain, Fakultas Seni Rupa \& Desain, Universitas Trisakti \\ Jl. Kyai Tapa No.1 Jakarta Barat 11440, Tlp. 0818922342 \\ Magister Pendidikan Dasar, Universitas Negeri Yogyakarta \\ Jl. Colombo No.1 Yogyakarta 55281, Tlp. 08970647260 \\ E-mail: wegig@trisakti.ac.id, miftakhuddin.2018@student.uny.ac.id
}

\begin{abstract}
Sri Tanjung's reliefs are displayed on the exterior wall of the second terrace of Penataran Temple, East Java. The community believes it narrative lifts the story of the Banyuwangi legend from Middle Javanese era. There are figures of Sri Tanjung following the signifier of trees, animals, and natural forms in decorative style. Some studies have tried to interpret relief from the other perspective. Rupabheda exists as aesthetic theory which forms the basis of the new interpretation method. Through the semiotic method, relief is assumed to be a representation of signs and symbols (consisting of signifier and signified). The analysis is done by connecting these elements with denotatum, ground, and interpretant. Rupabheda analysis manages to examine the shift in the meaning of various signs found in Hindu statues. This study found a renewal of meaning in the identification of figures. Sri Tanjung's relief visualization has disguised the icons of Middle Javanese culture of Hindu statues' relief. This study found that this relief has included a narrative of a different local story from the epic Mahabarata-Ramayana in the Hindu architectural site.
\end{abstract}

Keywords: Rupabheda, Relief, Sri Tanjung, Semiotic

\begin{abstract}
ABSTRAK
Relief Sri Tanjung terpampang pada dinding luar pendapa teras ke-dua Candi Panataran, Blitar, Jawa Timur. Masyarakat meyakini, narasi relief tersebut mengangkat cerita legenda Banyuwangi zaman Jawa Pertengahan. Di dalam relief terlihat adanya figur-figur dalam lakon cerita Sri Tanjung berikut penanda pepohonan, hewan, atau bentuk alam lain dalam gaya dekoratif. Beberapa penelitian telah berusaha menafsir relief dari sisi yang lain. Tetapi Rupabheda hadir sebagai teori estetika yang menjadi dasar penafsiran yang baru. Melalui metode semiotika, relief diasumsikan sebagai representasi tanda dan simbol (terdiri atas signifier dan signified). Analisis dilakukan dengan menghubungkan unsur-unsur tersebut dengan denotatum, ground, and interpretant. Analisis Rupabheda berhasil menelaah pergeseran makna dari beragam tanda yang terdapat pada arca Hindu. Penelitian ini menemukan adanya kebaruan makna dalam identifikasi tokoh-tokoh di dalam relief. Visualisasi relief cerita Sri Tanjung telah menyamarkan ikon budaya Jawa Pertengahan dalam relief arca Hindu. Temuan penelitian ini menunjukkan bahwa relief Sri Tanjung telah memasukkan narasi cerita lokal yang berbeda dengan epik Mahabarata - Ramayana dalam situs bangunan Hindu
\end{abstract}

Kata Kunci: Rupabheda, Relief, Sri Tanjung, Semiotik

\section{PENDAHULUAN}

Relief SriTanjung terpampang di dinding pendapa teras ke-dua Candi Penataran. Situs bersejarah yang berdiri pada tahun 1320 masehi ini, menampilkan bentuk abstrak ${ }^{i}$ figur manusia dengan beragam tanda dan simbol. Terlihat visualisasi pepohonan, hewan, bangunan, dan alam. Bentuk-bentuk abstrak 
dekoratif pada relief ini telah menghasilkan beragam penafsiran. Narasi relief Sri Tanjung bermula dari kidung ruwatan penyucian diri yang kemudian berkembang menjadi cerita Panji. Adegan dalam relief Sri Tanjung menceritakan kesetiaan Sri Tanjung kepada suaminya Sidapaksa (Susetyo, 2002, hlm 87). Relief Sri Tanjung tidak hanya ada di Candi Penataran. Beberapa relief juga ditemukan di Candi Surawana Kediri, Candi Jabung di Probolinggo, dan Candi Bajang Ratu di Mojokerto. Penelitian ini berfokus pada relief Sri Tanjung yang ada di Candi Penataran di Blitar.

Kieven (2004, hlm. 4) di dalam tulisannya, SimbolismeCeritaPanjidalam Relief-ReliefdiCandi Zaman Majapahit dan Nilainya pada Masa Kini, menyebutkan bahwa relief yang ada di Candi Penataran adalah figur Panji Asmarabangun dengan Putri Galuh Candrakirana. Terdapat adegan yang menggambarkan: a) relief pria dan perempuan duduk dengan sikap tubuh saling bermesraan; b) perjalanan figur pria bertopi (tekes) bersama punakawan atau Kadeyan-Kertolo dan Jurudeh; c) sikap tubuh yang menggambarkan hubungan seksual; d) pertemuan dengan pertapa; dan e) menyeberang perairan dengan menaiki ikan ${ }^{\mathrm{ii}}$. Analisis Kieven terhadap relief Sri Tanjung merujuk pada lakon Panji Asmarabangun dengan Putri Galuh Candrakirana. Analisis ini berbeda dengan dongeng yang tersebar di masyarakat. Relief Sri Tanjung di Candi Penataran menurut masyarakat lokal adalah perwujudan dari kidung yang telah menjadi legenda Banyuwangi (Ibu kota Kerajaan Blambangan). Poerbatjaraka (Sedyawati, 2001, hlm. 4) menegaskan bahwa cerita Sri Tanjung berasal dari kitab-kitab dalam kelompok bahasa Jawa Pertengahan yang tersaji dalam bentuk puisi atau kidung, di antaranya: Dewaruci, Sudamala, Panji Anggraeni, dan Sri Tanjung itu sendiriiii.

Menurut Rustarmadi (2014, hlm. 175), di dalam relief Sri Tanjung pada Candi Penataran, tokoh yang menggunakan topi tekes adalah: Sidapaksa, Sang Satyawan, dan Gagang Akingiv. Analisisnya juga menegaskan bahwa tokoh Sidapaksa berperan sebagai tokoh utama dalam cerita Sri Tanjung. Akan tetapi, pada analisis Kieven (2004, hlm. 4) mengidentifikasi bahwa figur yang digambarkan adalah: Kartolo dan Punakawan yang terdapat di Candi Kendalisodo, Gunung Penanggungan. Menurut Kieven, relief ini penggambaran Panji Asmarabangun dengan Putri Galuh Candrakirana. Figur-figur serupa yang menjadi objek penelitian Kieven juga terdapat dalam relief Candi Jabung di Ponorogo, Candi Surawana di Kediri, dan Candi Miri Gambar di Tulung Agung. Selanjutnya, Kieven menanggapi:

"... terdapat alur penceritaan yang sama dalam cerita Panji, yaitu perpisahan, saling mencari, dan menyatu, adalah ciri khas untuk semua cerita Panji. Namun ada perbedaan antara medium gambar dan medium sastra: Dalam cerita Panji sebagai karya sastra sering muncul adegan peperangan, sedangkan dalam gambar relief yang saya teliti, tokoh Panji sama sekali tidak bertindak sebagai prajurit yang berperang." (Kieven, 2014, hlm. 4)v. 
Analisis Kieven mengenai cerita Panji, menunjukkan sastra Panji adalah salah satu contoh khas dari kreativitas pada zaman pertengahan Jawa Timur. Baiknaskah maupun versi lisannya diciptakan pada waktu itu tidak didasarkan pada sastra India ${ }^{\text {vi }}$. Kemiripan cerita inilah yang kemudian menghasilkan penafsiran terhadap relief Sri Tanjung. Sementara itu bentuk visual relief-relief Sri Tanjung mengarah ke bentuk abstrak dekoratif yang menyulitkan pengamat untuk membaca setiap adegannya. Terlebih lagi, analisis Kieven mengenai relief Sri Tanjung sebagai Panji Asmarabangun berlawanan dengan pendapat para ahli lainnya, walaupun pada dasarnya ia mengungkapkan penghargaannya terhadap kemandirian sastra Jawa di zaman Majapahit, berupa kidung Sri Tanjung yang menggunakan bahasa Jawa Pertengahan (Sedyawati, 2001, hlm 4). Perbedaan penafsiran ini membuka peluang untuk dilakukan penafsiran ulang terhadap relief Sri Tanjung menggunakan pendekatan yang berbeda.

Metode interpretasi yang dilakukan oleh peneliti terhadap suatu relief ada kemungkinan berbeda dengan konsep yang digagas pencipta. Pematung pada proses kreatifnya melakukan ritual prosesi yoga untuk menyatukan diri dengan calon ciptaannya (Harto, 2014, hlm. 28; Istanto \& Syafii, 2017, hlm. 20; Wirjosuparto, 1956, hlm. 7). Di dalam kitab Manasara, Uku mengenai tata arsitektur, menyebutkan motif relief yang tepat. Hanya disebutkan bahwa situs candi dapat dihiasi dengan pahatan (Jordaan, 2009, hlm. 121). Kesenjangan ini perlu dijembatani oleh sebuah pisau analisis yang lebih tajam dan tepat sasaran, yaitu Rupabheda.

Penelitian interpretatif terhadap relief Sri Tanjung di Candi Penataran dengan metode analisis Rupabheda perlu dilakukan untuk menjawab permasalahan: 1) Bagaimana kaidah estetika Hindu diterapkan pada relief Candi pada zaman Jawa Pertengahan (abad 11-15 M)?; 2) Bagaimanakah proses peralihan estetik budaya Hindu ke budaya Jawa Pertengahan?. Melalui penelitian ini, diperoleh pemaknaan baru terhadap relief Sri Tanjung di Candi Penataran. Gambar relief yang berkarakter naratif-dekoratif di sana dapat mengidentifikasi perbedaan pengodean tanda.

\section{METODE}

Metode penelitian menggunakan metode semiotika, di mana relief dipandang sebagai sesuatu yang mempresentasikan tanda dan simbol. Tanda atau simbol yang dipresentasikan, menurut Saussure, terdiri atas penanda (signifier atau artikulasi suara atau bentuk visual) dan petanda (signified atau makna). Lebih lanjut, simbol akan berfungsi apabila unsur-unsur tanda saling berhubungan, antara: a) objek (denotatum) suatu keadaan yang ditampilkan melalui tanda; b) latar belakang (ground) yang dimiliki oleh penafsir tanda; dan c) subjek (interpretant) vii. Subjek yang ditafsirkan terhadap objek dan latar belakang akan memunculkan pengertian tanda pada benak orang yang menggunakan tanda, sehingga tanda yang orisinal dapat berkembang menjadi tanda baru. Dalam analisis Barthes, dikatakan sebagai tataran 
denotasi dan konotasi. Denotasi adalah tanda yang sebenar-benarnya dan memperoleh pengakuan sosial. Sedangkan makna konotasi merupakan petanda yang memiliki keterbukaan makna secara implisit. Artinya, tidak langsung dan tidak pasti, sehingga terbuka atau membuka kemungkinan untuk penafsiran-penafsiran baru ${ }^{\text {viii }}$. Melalui metode ini, akan ditemukan makna-makna baru dalam suatu simbol atau tanda. Sebagaimana halnya dalam penelitian Supriatna (2014, hlm, 280) yang berhasil menemukan makna-makna interpretatif dalam suatu karya seni, bahwa suatu aksesoris atau ornamen yang melekat pada karya seni tidak saja bersifat estetis, melainkan menjadi bagian dari narasi karya seni itu sendiri. Demikian pula penemun makna baru dalam ukiran Gorga oleh Sianipar, et. al (2015).

\section{HASIL DAN PEMBAHASAN}

\section{Kajian Rupabheda dalam Pembacaan Gambar}

Dalam kaidah estetika Hindu, terdapat 6 (enam) kriteria untuk menciptakan relief sebagai bentuk karya seni (Istanto, 2018, hlm. 158; Jamharil, 2010, hlm. 141). Keenamnya adalah: Sadrsya, Pramana, Warnikabhangga, Bhawa, Lhawa, dan Rupabheda (Gandhi, 2010, hlm. 57; Sedyawati, 1981, hlm. 14). Meski demikian, hanya ada 3 (tiga) kaidah yang mendasari analisis terhadap ciri khas setiap tokoh dalam relief Sri Tanjung, antara lain: Pramana, Lhawa, dan Rupabheda. Pramana artinya kesesuaian ukuran dalam figurfigur yang berusaha diwujudkan. Lhawa berarti daya pesona sebagai ekspresi yang membangun makna transendental. Hadirnya Lhawa dalam suatu karya seni, menurut Sumardjo (2000, hlm. 26), akan menimbulkan kesan yang mendalam pada penikmat, bahkan bisa memengaruhi batinnya. Sedangkan Rupabheda artinya pembedaan bentuk atau karakter. Maksudnya, bentuk-bentuk yang digambarkan harus dapat segera dikenali oleh orang yang melihatnya (Sedyawati: 1981, hlm. 48). Inilah ciri ikonografi yang khas dan paling menonjol dalam suatu karya seni berbentuk relief (Munandar, 2018, hlm. 45-53)

Berbeda dengan teknik interpretasi ikonografi Panofsky (1971) yang digunakan oleh Adnyana, et. al (2017) dan Adnyana, et. al (2018) untuk mengungkap multinarasi yang dalam pada relief Yeh Pulu, perspektif Rupabheda lebih tepat dipakai untuk meneliti peralihan dari Hindu ke Jawa Pertengahan, dikarenakan Rupabheda menampilkan variasi yang mendalam dan terperinci dalam seluruh keragaman. Misalnya manusia dan tipe penjelmaannya sebagai dewa, dewi, raja, ratu, rakyat jelata, dan binatang (Sharma, 2016, hlm. 35). Terlebih lagi menurut penelitian Mustaqin (2017, hlm. 374), suatu relief atau ukiran bisa saja mempunyai beberapa dimensi yang diselesaikan dengan teknik simplifikasi dan deformasi. Salah satu contohnya adalah patung Liong di kuil Tay Kak Sie, di Semarang, yang merupakan bentuk imitatif dari binatang mitologi Cina. Penelitian Mustaqin (2017, 378) juga mengungkapkan, bahwa ornamen dalam patung Liong tersebut menggambarkan amarah, ambisi, dan ketegasan. Lebih lanjut, ia juga menegaskan bahwa penggambaran patung beserta ornamennya tersebut lebih 
banyak dipengaruhi oleh beberapa faktor, termasuk seniman pembuatnya, budaya yang dianut, pengaruh atas asal usulnya dari dinasti Ming, lokasi kelenteng, dan kepercayaan.

Temuan-temuan semacam inilah yang perlu diperhatikan sebagai alasan penggunakan Rupabheda untuk pembacaan gambar relief candi Penataran. Sebab, rupabheda pada dasarnya adalah pengetahuan tentang penampilan (Sherma, 2016, hlm. 35). Objek dari suatu subjek diklasifikasikan sebagai jiwa yang berarti hidup, dan ajiwa yang berarti tidak hidup. Untuk kategori hidup, terbagi menjadi tiga: Uttam (kategori semua karakter unggul, seperti: dewa, dewi, raja); Madhyam (kategori permaisuri); dan Adham (kategori setan dan semua yang menjijikkan atau tampak jelek). Sedangkan yang tidak hidup adalah seluruh latar belakang dan benda-benda pendukung, seperti: gunung, awan, batu, dan lain-lain. Rupa berarti bentuk (baik visual maupun mental) dan bheda berarti diferensiasi atau karakterisasi, seperti perbedaan antara bentuk insting kehidupan dan keindahan. Demikian juga bentuk-bentuk yang tidak memiliki keindahan dan tidak memiliki kehidupan.

Rupabheda terdiri dari pengetahuan tentang karakteristik khusus benda-benda (alami atau buatan manusia). Misalnya, perbedaanpenampilanantarabanyakjenispria, wanita atau benda alami sekaligus sifat-sifat yang menyertainya. Praktis, mempergunakan Rupabheda dalam suatu aktivitas ilmiah akan memungkinkan seseorang untuk dapat melihat dan menggambarkan segala sesuatu sebagaimana adanya dan sebagaimana mereka tampak secara visual maupun mental
(Sharma, 2016, hlm. 35).

Oleh karena itu, penelitian ini khusus menganalisis relief Sri Tanjung di Candi Penataran menggunakan teori estetika Rupabheda. Pada tahap selanjutnya, relief Sri Tanjung dianalisis menggunakan teori Geertz (2000, hlm. 3) mengenai thick description terhadap kebudayaan. Pendekatan tersebut diaplikasikan melalui penafsiran simbol makna kultural secara mendalam dan menyeluruh dari perspektif para pelaku kebudayaan itu sendiri. Sebab, kebudayaan adalah sesuatu yang semiotik dan bersifat semiotis, di mana hal-hal yang berhubungan dengan simbol diberlakukan oleh masyarakat yang bersangkutan (Geertz, 2000, hlm. 3).

Kajian analisis Rupabheda digunakan dalam penafasiran relief Sri Tanjung, dengan dua pertimbangan berikut. Pertama, relief sebagai bentuk ilustrasi abstrak dekoratif kurang terlihat secara jelas. Menurut kidung Sri Tanjung, sebagaimana disampaikan juga oleh Atmodjo (1978, hlm. 4) dan Endraswara (2013, hlm. 151), tokoh bernama Sri Tanjung adalah sosok wanita ideal bagi masyarakat Jawa. Ia jelita, tinggi semampai, luwes, dan memesona. Tokoh Sidapaksa merupakan ksatria yang tampan, perkasa, santun, rendah hati, dan berbudi luhur.

Adapun tokoh Raja Sulakrama memiliki karakter pribadi yang rakus, serakah, sombong, dan berwatak dengki. Sedangkan tokoh Begawan Tambapetra ialah orang yang sabar dan menjunjung tinggi moralitas. Ciriciri karakter tersebut hampir tidak nampak jika dilihat dari bentuk visual relief Sri Tanjung. 


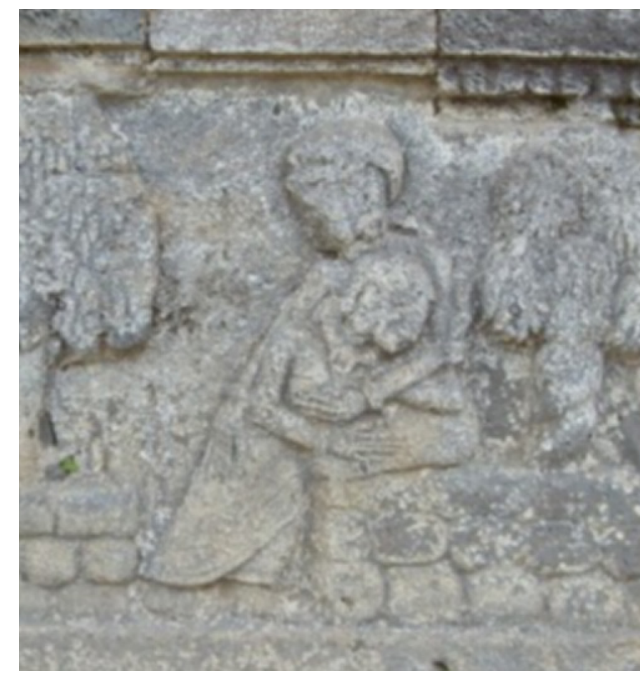

Gambar 1. Sungkem sebagai penghormatan kepada yang dituakan atau orang tua (Sumber: wikiwand.com)

Kedua, terjadi beragam penafsiran terhadap beberapa adegan pada relief Sri Tanjung. Sebagai contoh, gambaran seorang perempuan bersandar di dada laki-laki (Gambar 1). Kieven (2004, hlm. 4) menafsirkan gambaran itu sebagai adegan laki-laki dan perempuan dalam sikap tubuh berhubungan

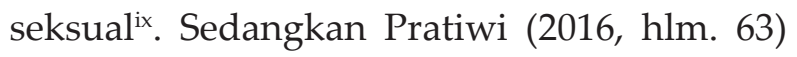
menafsirkan adegan tersebut sebagai posisi sungkem (menyembah dengan rasa hormat), yang telah menjadi kebiasaan yang dilakukan masyarakat Jawa. Umumnya dilakukan sebagai simbol penghormatan dan kepatuhan oleh istri kepada suami atau oleh anak atau yang lebih muda kepada orang tua ${ }^{x}$. Fungsi inilah yang oleh Sunaryo (2009, hlm. 4) disebut sebagai fungsi simbolis. Interpretasi atas relief ini menegaskan bahwa telah terjadi peralihan dari budaya Hindu ke budaya Jawa Pertengahan. Di mana perempuan Jawa dalam periode Klasik Tua mempunyai kedudukan yang sama dengan pria (Indradjaja, 2017, hlm. 106).

\section{Hirarki Keruangan di Candi Penataran}

Candi Penataran ditemukan pada 1815 oleh Sir Thomas Stamford Raffles (1781-1826), Letnan Gubernur Jendral kolonial Inggris yang berkuasa di Nusantara pada 1811-1816. Raffles bersama dengan Dr. Horsfield telah membukukan penemuan ini dalam bukunya The History of Java (1817). Nama Penataran, merujuk pada pustaka Kidung Margasmara, dalam Kakawin Nagarakertagama tahun 1380 Saka atau 1458 Masehi, yang disebut Palah (Nagarakertagama pupuh XVII, pupuh LXI: 02, pupuh LXXVIII: 02) ${ }^{\mathrm{xi}}$.

Bangunan menempati areal tanah seluas 12.946 persegi $^{\mathrm{xi}}$, yang terdiri atas beberapa situs, sehingga lebih tepat disebut sebagai komplek Candi. Lokasi bangunan terletak di lereng barat daya Gunung Kelud pada ketinggian 450 meter di atas permukaan laut, di desa yang juga bernama Penataran, Kecamatan Nglegok, Kabupaten Blitar, Jawa Timur.

Halaman komplek Candi dibagi menjadi tiga bagian: halaman pertama, halaman kedua, dan halaman ketiga. Pembagian halaman komplek Candi berpedoman pada kepercayaan Hindu yang disebut Tri Mandala, yaitu pembagian lokasi berdasarkan letak, fungsi, dan tingkat kesuciannya, yang disebut nista, madya, dan utama. Konsepsi Tri Mandala sesuai dengan konsepsi bangunan Candi Hindu, Tri Loka yaitu: Bhur Loka (dunia bawah), Bwah Loka (dunia tengah), dan Swah Loka (dunia atas), yang sejalan juga dengan konsepsi tahapan relief Candi Borobudur yaitu: Kamadhatu, Ruphadatu, dan Aruphadatu. Namun demikian, pembagian tiga lokasi ini 


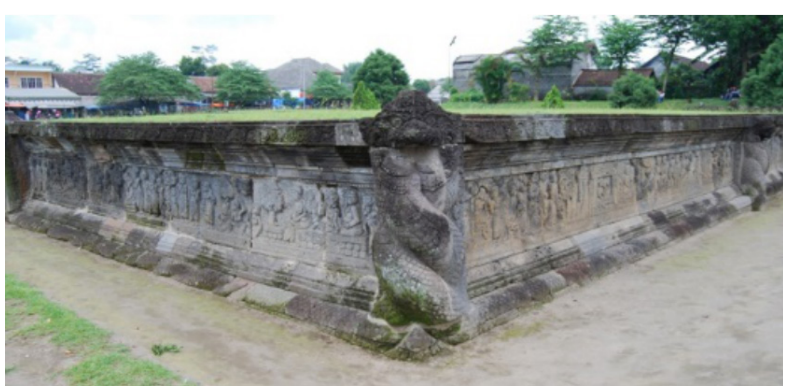

Gambar 2. Pendapa Teras atau Batur Pendopo. (Sumber: Kirno. 2019)

didasarkan pada dikotomi atas-bawah atau depan-belakang untuk menunjukkan urutan tingkat kesucian (Degroot, 2015, hlm. 35).

Berdasarkan tiga konsepsi tersebut, bisa diartikan bahwa lokasi pertama sebagai alam keinginan duniawi, lokasi kedua sebagai alam perbaikan, dan lokasi ketiga sebagai alam ketiadaan yang suci ${ }^{\text {xiii }}$. Menurut ikonografi bangunan Hindu, halaman depan berarti alam kemanusiaan yang dipenuhi hawa nafsu. Sedangkan Candi induk, umumnya terletak paling belakang sebagai bangunan suci, yang secara filosofis menempati strata tertinggi. Relief Sri Tanjung yang dimaksud dalam penelitian ini, terletak di pendapa teras kedua halaman depan komplek Candi Penataran (Gambar 2.). Akan tetapi, kandungan isi relief Sri Tanjung menyerupai kandungan isi relief Kamadhatu di balustrade lantai dasar Candi Borobudur, yang kini terpendam tanah. Relief Sri Tanjung lebih bersifat arsitektural (Munandar, 1999, hlm. 51) dan merupakan relief naratif sekaligus dekoratif, karena berfungsi sebagai ornamen dan berusaha menyampaikan suatu cerita (Holt, 2000, hlm. 46; Jordaan, 2009, hlm. 121).

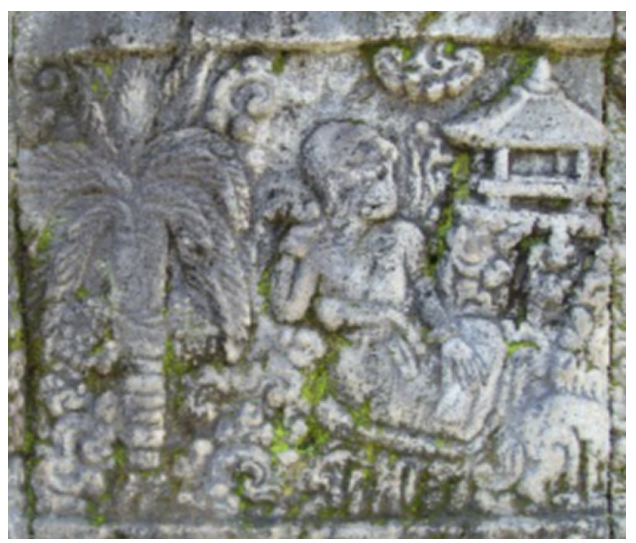

Gambar 3. Adegan ke-1

(Sumber: koleksi pribadi)

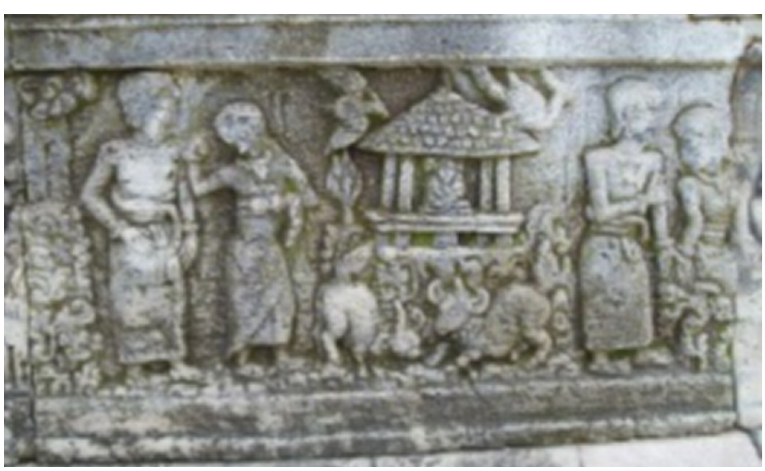

Gambar 4. Adegan ke-2

(Sumber: koleksi pribadi)

\section{Analisis Narasi dan Suasana Relief Sri Tanjung}

Relief Sri Tanjung di pendapa teras kedua memiliki kelengkapan gambaran cerita Sri Tanjung sebagaimana bisa dilihat dalam analisis gambar 3. Dalam adegan ke-1, Patih Sidapaksa hendak berangkat ke Swargaloka untuk menyampaikan surat Raja Sulakrama kepada Dewa. Sidapaksa duduk bersila dengan tangan kanan menyangga kepala. Sebagai patih kerajaan, Sidakpaksa tidak mau mengkhianati kepercayaan yang dibebankan kepadanya. Sedangkan dalam adegan kedua, Sidapaksa tampak berpamitan kepada Sri Tanjung.

Dalam adegan ke-2, Sidapaksa dan Sri Tanjung berjalan beriringan. Sidapaksa berpamitan dengan posisi berdiri dan Sri 
Tanjung duduk memberikan selendang. Selendang ini merupakan selendang pemberian ibunya (bidadari) dengan tujuan agar Sidapaksa bisa terbang ke Swargaloka.

Hasil analisis terhadap relief-relief di atas menunjukkan bahwa, penggambaran tokoh di candi-candi Jawa Timur tidak lagi naturalis, terlihat kaku, dengan posisi tokoh menghadap ke samping (en-profile). Hal ini merupakan bentuk relief rendah (bas-relief) dan adanya horror vacui yaitu ketakutan terhadap bidang kosong sehingga jarak pada relief diisi penuh (Munandar, 1999, hlm. 50). Perubahan ini terjadi sejak masa pemerintahan Raja Srengga, di mana karya-karya seni rupa pada candicandi di Jawa Timur (termasuk juga Candi Penataran) mulai menampakkan budaya Jawa yang asli. Paham Hinduisme mulai berakulturasi dengan budaya kejawen, sebagai kepercayaan asli orang Jawa. Demikianlah menurut Iswati (2016, hlm. 15), bahwa produk kesenian bercorak Indonesia-Hindu tidak bisa lepas dari aspek kontekstualitasnya, serta aspek religius dan kultus raja (Prawira, 2001, hlm. 61).

Bentuk-bentuk distorsi tersebut merupakan proses pembentukan, yang menurut Soedarso dipengaruhi oleh adanya bentuk wayang, yang terlahir sebagai kebudayaan Jawa asli, jauh sebelum budaya Hinduisme datang dan berkembang di tanah Jawa (Soedarso: 1978, hlm. 46). Bentuk-bentuk wayang sebagai distorsi dari bentuk manusia dalam perwujudannya mengacu kepada konsepsi kebudayaan seni rupa prasejarah, yang menjadi perlambang di rumahrumah tinggal sekaligus dalam acara ritual peribadatan. Adapun perwujudan ruh nenek moyang dimanifestasikan dalam bentuk distorsi manusia maupun binatang yang disakralkan dan digunakan sebagai penjaga rumah, seperti: kadal, ular, burung, harimau, kerbau, dan lain sebagainya (Degroot, 2006, hlm. 68). Dalam beberapa literatur, hewan yang dijadikan simbol disesuaikan dengan kesamaan antara sifat hewan dengan kesan atau sikap dari wujud manusia yang didistorsikan (Totton, 2003, hlm. 6). Oleh karena itu, simbol hewan juga kerap ditemui dalam bangunan candi (Totton, 2011, hlm. 7).

Dalam relief Sri Tanjung yang terakhir, nampak Sidapaksa dan Sri Tanjung duduk berpangkuan. Representasi ini menunjukkan suatu bentuk metafor visual tercapainya ketentraman dan keharmonisan dalam hidup. Manusia yang telah mencapai kesucian hati dan pikirannya, maka ia akan mencapai kesempurnaan. Menurut paham Hindu yang melatarbelakangi penyusunan relief Sri Tanjung, kesempurnaan diartikan sebagai tingkatan kualitas tertinggi penyatunya jiwa manusia dengan Sang Pencipta atau Atman, . Hal tersebut berkesinambungan dengan konsep budaya Jawa (kejawen), yang menyebutkan bahwa manusia yang sempurna adalah manusia yang telah menyatu dengan Tuhannya, atau yang disebut Manunggal. Manunggal berarti Tuhan berada di dalam diri manusia, menjadi isi hati yang tidak bisa dipisahkan (Manunggal artinya menjadi tunggal atau menyatu). Oleh karena itu, konsep Manunggaling Kawula Gusti lazim disebut insan kamil, yaitu manusia yang sempurna dari wujud dan pengetahuannya. 
Kesempurnaan dari segi wujud ialah karena Ia merupakan manifestasi sempurna, yang pada dirinya tercermin nama-nama dan sifat Tuhan secara utuh, sedangkan kesempurnaan dari segi pengetahuannya ialah karena ia telah mencapai tingkatan tertinggi melalui kesadaran atas kesatuan esensinya dengan Tuhan.

Tabel 1 merupakan analisis denotasikonotasi suasana yang terbangun dalam relief Sri Tanjung Candi Penatara. Berdasarkan analisis pada tabel 1, dapat ditegaskan bahwa ke-Rupabheda-an penanda dapat dimaknai secara berbeda. Telah terjadi pergeseran pemaknaan yang awalnya secara filosofis dari cerita epik Mahabarata-Ramayana menuju pemaknaan secara filosofis dari budaya Jawa Pertengahan. Pemaknaan yang baru tersebut bersumber pada kondisi alam dan mitos kejawen. Oleh karenanya, wajar apabila terjadi perbedaan penafsiran di antara para ahli yang meneliti relief candi-candi di Jawa Timur, termasuk relief Sri Tanjung.

Cara membaca relief tidak seperti cara membaca foto atau gambar hasil pemotretan, tetapi seperti cara membaca film atau kartun yang berseri. Prasetya (2016, hlm. 301) lebih lanjut lagi menjelaskan bahwa relief Ramayana pada Candi Prambanan merupakan relief naratif yang dari relief ini kemudian dapat dibaca ciri-ciri elemen visual yang mengarah pada budaya agama Hindu.

Teknik pahatan relief Sri Tanjung dan relief-relief lain yang terdapat pada dinding teras Pendapa Candi Penataran termasuk ke dalam gaya pahatan rendah, di mana dimensi kebentukan proporsi tubuh manusia, binatang,
Tabel 1. Unsur Alam sebagai Referensi dalam Penanda Relief Cerita Sri Tanjung

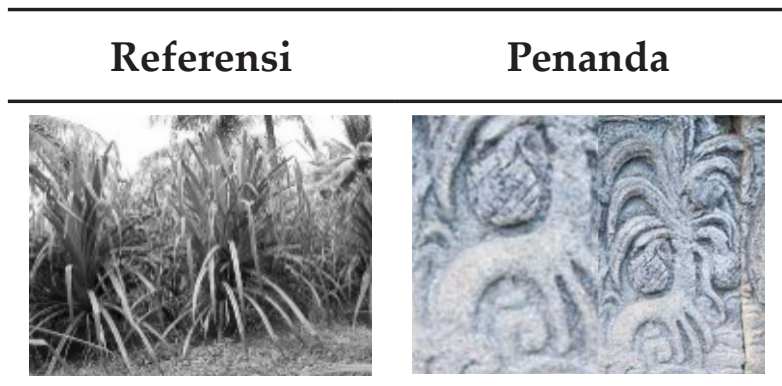

Adanya penanda tanaman pandan laut menunjukkan bahwa adegan demi adegan dalam relief Sri Tanjung berlokasi di tepi pantai.

Di mana pusat kebudayaan Jawa Pertengahan pada masa itu berada di pesisir Pantai Selatan Pulau Jawa

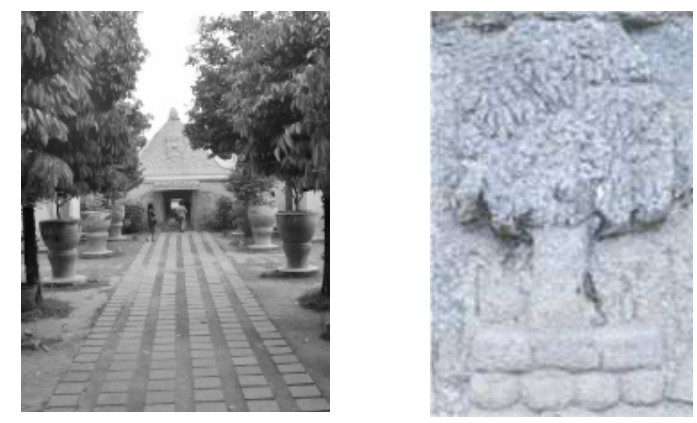

Pohon kepel sebagai penanda yang memiliki kemiripan dengan gunungan wayang, diyakini sebagai pohon dan buah yang ditanam oleh kalangan priyayi. Di mana ada pohon kepel, maka di sana ada keraton atau pusat pemerintahan. Gunungan adalah bentuk wayang kulit sebagai penanda awal dan akhir cerita
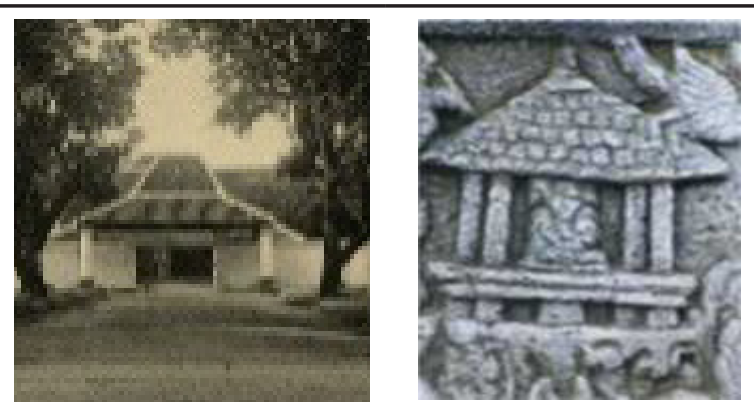

Bangunan mirip pendapa beratap limas atau joglo. Rumah khas Jawa ini yang berbentuk penanda segitiga diyakini sebagai miniatur gunung Meru. 

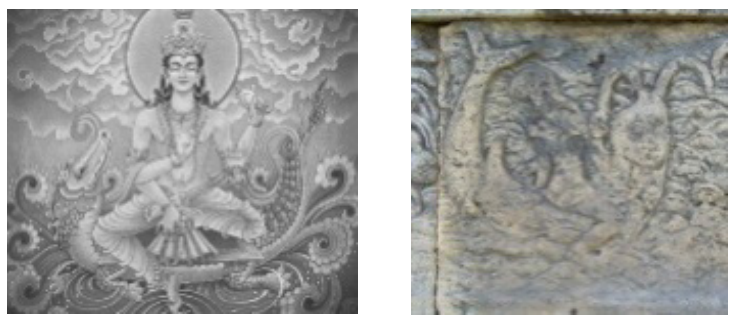

Ikan laut, dalam tafsiran Lydia Kieven, sejenis makhluk penolong seperti ikan lumba-lumba sebagai penanda. Dalam versi kidung, sebagai kendaraan Dewa Baruna. Diilustrasikan perpaduan antara tubuh ikan berkepala udang.

dan tumbuhan tidak mengejar kemiripan dengan figur manusia sesungguhnya. Akan tetapi ada satu hal yang bisa dijadikan pegangan guna menafsirkan adegan demi adegan dalam relief tersebut, yaitu tandatanda yang menjadi perlengkapan setiap tokoh. Meskipun relief itu bisa jadi merupakan bentuk pengabdian dan penghormatan terhadap seorang pembesar (Syafii \& Rohidi, 1987, hlm. 3), namun tanda-tanda itulah yang berfungsi sebagai penanda Rupabheda.

Melalui analisis Rupabheda, penulis membaca tanda-tanda yang masih nampak pada setiap tokoh relief Sri Tanjung, antara lain topi tekes, mahkota, subang, hara, keyura, upawita, pohon palem, pohon kepel, pandan laut, dan lain sebagainya. Tanda-tanda itu kendati masih menggunakan nama-nama dari India, tetapi secara bentuk sudah sangat jauh kemiripannya dari aturan silpasastra seni arca India. Tanda-tanda itu sengaja diwujudkan oleh pemahatnya untuk keperluan menata tokoh-tokoh cerita semata, supaya tidak tertukar antara tokoh yang satu dengan yang lainnya. Di samping itu, tanda-tanda itu sengaja dipahat sedemikian rupa juga untuk menyampaikan pesan akan kemandirian

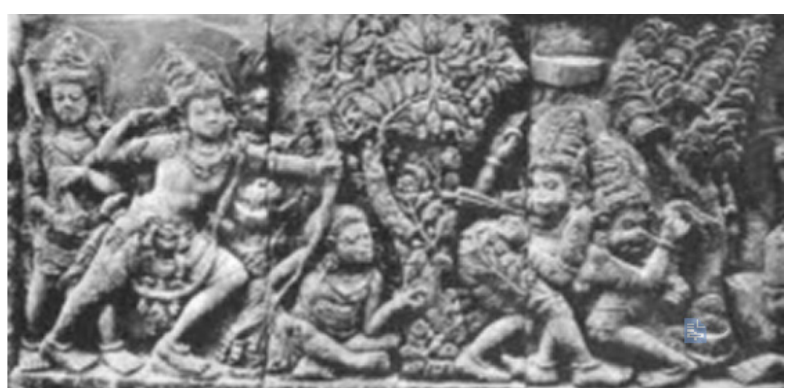

Gambar 5. Relief Ramayana pada Candi Prambanan (Sumber: wayangku.id)

kerajaan-kerajaan di Jawa Timur dari doktrin seni budaya India. Temuan ini sejalan dengan hasil penelitian Royo-iyer (1991, hlm. 13) terhadap relief Candi di Jawa, bahwa tidak ada kemiripan yang spesifik dengan bentuk model pahatan di India.

\section{Analisis Figur Tokoh-tokoh dalam Relief Sri} Tanjung

Dalam menganalisis Rupabheda relief Sri Tanjung pada Tabel 2 dan Tabel 3, penulis memaparkan setiap tanda yang menjadi ciri khas identitas setiap tokohnya. Ada enam tokoh yang berperan dalam relief Sri Tanjung, antara lain: Sri Tanjung, Raden Sidapaksa, Raja Sulakrama, Begawan Tambapetra, dan Punakawan. Relief dilengkapi dengan adanya hewan, tetumbuhan, dan bangunan rumah, yang menjadi ciri latar belakang penceritaan dalam relief Sri Tanjung. Berikut ini analisis denotasi-konotasi karakter tokoh Sri Tanjung dalam relief Sri Tanjung Candi Penataran:

Berdasarkan penanda atau Rupabheda relief Sri Tanjung, dapat disimpulkan bahwa memang terdapat pergeseran pemaknaan arti feminisme dari filosofis Hindu ke mitologi Jawa Pertengahan. Pada masa itu, karya seni idealnya dikaitkan dengan mitos dan tata aturan keagamaan (Sari \& Pramono, 2008, hlm. 76). 
Tabel 2. Unsur Alam sebagai Referensi dalam Penanda Relief Cerita Sri Tanjung

\begin{tabular}{cl}
$\begin{array}{c}\text { Penanda } \\
\text { Relief Panel 1 }\end{array}$ & $\begin{array}{c}\text { Analisis Makna } \\
\text { Denotatif atau } \\
\text { Konotatif Panel 1 }\end{array}$ \\
\hline & $\begin{array}{l}\text { Ciri fisik dipakainya } \\
\text { kain (Jw: Jarik) sebagai } \\
\text { identitas perempuan } \\
\text { Jawa. }\end{array}$ \\
& $\begin{array}{l}\text { Terlihat identitas dada } \\
\text { sosok perempuan yang } \\
\text { membedakan identitas } \\
\text { dengan figur pria }\end{array}$ \\
& $\begin{array}{l}\text { Sri Tanjung, sosok } \\
\text { wanita jelita, semampai, } \\
\text { luwes dan memesona } \\
\text { sebagai makna } \\
\text { konotatif. }\end{array}$ \\
\hline
\end{tabular}

Tabel 3. Analisis Rupabheda Relief Sri Tanjung pada Panel 1

\begin{tabular}{cc}
\hline Penanda & Analisis Makna \\
Relief Panel 2 & Denotatif atau \\
& Konotatif Panel 2 \\
\hline
\end{tabular}

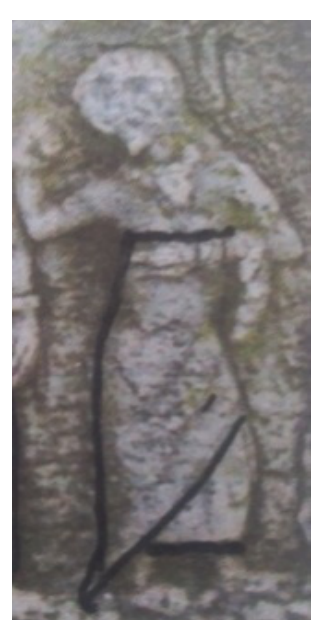

Sri Tanjung terlihat kembali cirikhas keJawa-annya memakai kemben. Pakaian wanita berupa kain panjang dengan garisgaris bukaan di depan, dilengkapi dengan selendang ${ }^{\mathrm{xv}}$.

\section{Sri Tanjung} mengenakan sabuk tepat di dadaguna mengikat kemben.

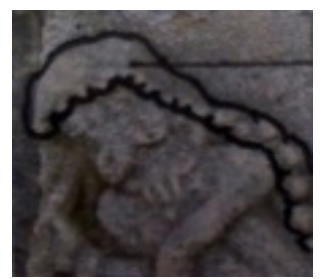

Sri Tanjung rambutnya terurai, menunjukkan kefiniman $^{\mathrm{xvi}}$.

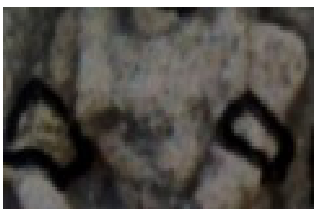

Mengenakan keyura, gelang atas dekat bahu, memiliki makna sebagai kerabat kraton atau kerajaan $^{\text {xvii. }}$

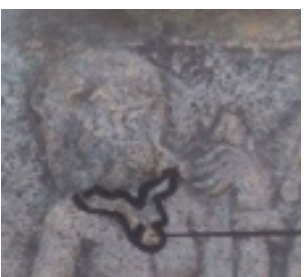

Mengenakan hara, sebutan untuk kalung guna menutup bagian payudara.

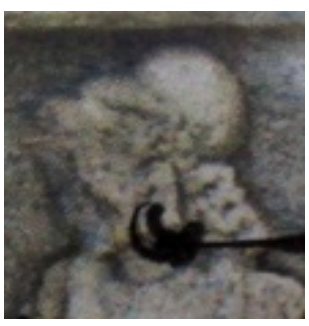

Sri Tanjung mengenakan subang, dimaknai menunjukkan identitas sebagai perempuan.

Bukti yang tergambar adalah adanya kemben sebagai tatacara berpakaian orang Jawa dan ornamen hias batik Bali, sebagaimana terlihat dalam relief ini. Berdasarkan penanda atau Rupabheda relief Sidapaksa di Tabel 4, tampak adanya pergeseran pemaknaan maskulinitas dari filosofis Hindu ke mitos Jawa Pertengahan. Hal ini utamanya terlihat dari gestur wajah yang tertunduk, menandakan sikap rendah hati. Demikian juga dengan mahkota yang dikenakan sudah terbuat dari kain dengan ornamen batik yang mengidentifikasikan busana Jawa. Sampai pada interpretasi ini, sedikitnya telah ditemukan tiga pergeseran dari yang semula bercorak Hindu menjadi bercorak budaya Jawa Pertengahan. Pertama, adalah pemaknaan unsur alam di dalam relief candi Penataran yang mengalami pergeseran makna filosofis dari epos Mahabarata Ramayana menuju makna filosofis dari budaya Jawa Pertengahan. Kedua, adalah pemaknaan arti feminisme dalam relief Sri Tanjung, dari filosofis Hindu menuju arti feminisme menurut budaya masyarkat pada Jawa Pertengahan. Ketiga, adalah pemaknaan arti maskulinitas dalam relief Sidapaksa, dari 
filosofis Hindu menuju budaya masyarakat pada Jawa Pertengahan.

Temuan penelitian ini dalam poin di atas sekaligus mengkonfirmasi penelitian Mustaqin (2017, hlm. 372) tentang makna suatu ornamen patung, dan mendiskonfirmasi temuan penelitian Julianto, Jodog, \& Santosa (2016, hlm. 24) tentang nilai interaksi simbol tradisi. Menurut penelitian Julianto, Jodog, \& Santosa (2016, hlm 24), fungsi esensi dari suatu simbol dalam pelinggih tidak berubah. Perubahan yang terjadi hanya sebatas aspek sosiologis di mana masyarakat menerima perubahan sebagai suatu fenonema kultural. Prinsip-prinsip ritual dalam pelinggih tetap dipertahankan, sedangkan konsep perwujudan pelinggih mengalami pembaruan akibat penyatuan nilai estetis, seni, spiritual, dan modernisasi dalam konteks kehidupan duniawi. Visualisasi simbol dalam upaya mengkomunikasikan pesan mengandung unsur akulturasi sistem budaya masyarakat pada masa tertentu untuk berinteraksi.

Berbeda dengan penelitian Julianto, Jodog, \& Santosa (2016, hlm. 31-32), yang menemukan bahwa pergeseran makna simbol hanya sebatas ranah praktis, penelitian ini menujukkan bahwa pergeseran telah melingkupi ranah substansi. Pergeseran ini tampak jelas utamanya sebagaimana ditemukan dalam relief Sri Tanjung dan relief Sidapaksa.

Sedangkan berdasarkan penanda atau Rupabheda relief Raja Sulakrama pada Tabel 5, terlihat dalam penggambaran relief ekspresi wajah Raja Sulakrama ialah pemarah dan/atau cemberut. Sedangkan kain wiru adalah
Tabel 4. Analisis Rupabheda Relief Sidapaksa

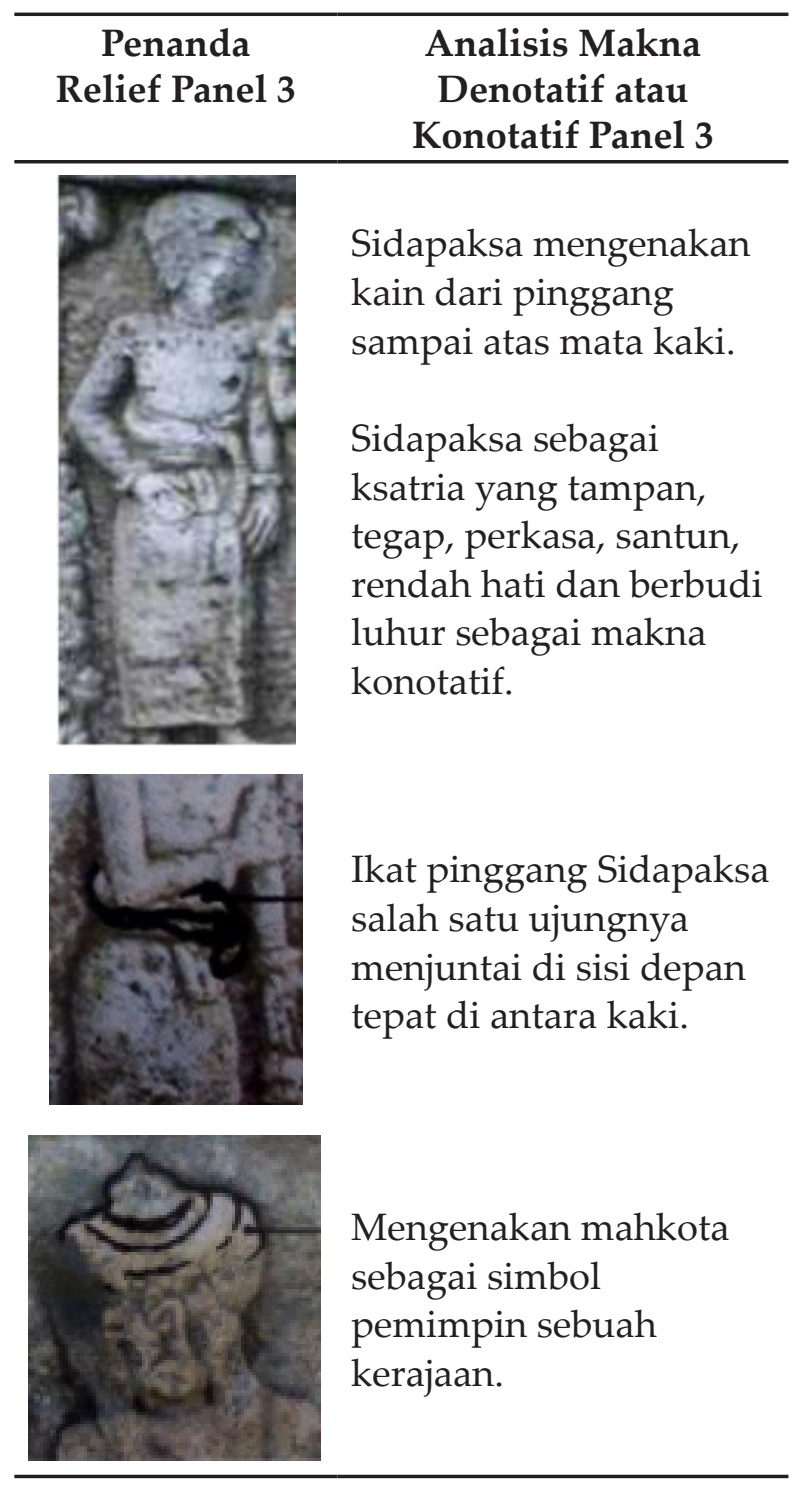

Tabel 5. Analisis Rupabheda Relief Tubuh Raja Sulakrama

\begin{tabular}{cl}
\hline $\begin{array}{c}\text { Penanda } \\
\text { Relief Panel 4 }\end{array}$ & $\begin{array}{c}\text { Analisis Makna } \\
\text { Denotatif atau } \\
\text { Konotatif Panel 4 }\end{array}$ \\
\hline & $\begin{array}{l}\text { Raja Sulakrama } \\
\text { menggunakan kain dari } \\
\text { pinggang sampai atas } \\
\text { mata kaki. Terdapat } \\
\text { wiru, yaitu lipatan kain } \\
\text { di sebelah kiri. } \\
\text { Dari mimik wajah } \\
\text { dan gesture tubuh, } \\
\text { terlihat Raja Sulakrama, } \\
\text { berwatak rakus, } \\
\text { serakah, sombong dan } \\
\text { dengki sebagai makna } \\
\text { konotatif. }\end{array}$
\end{tabular}




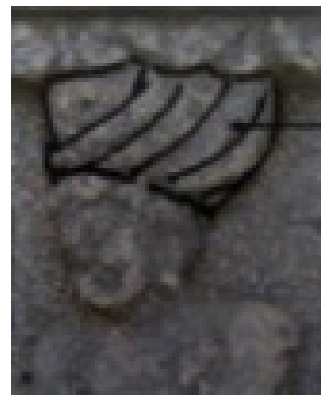

Rambut ditutup lipatan kain yang berulangulang disebut dengan Sorban.

Mengenakan hara atau kalung.

Mengenakan keyura atau gelang atas.
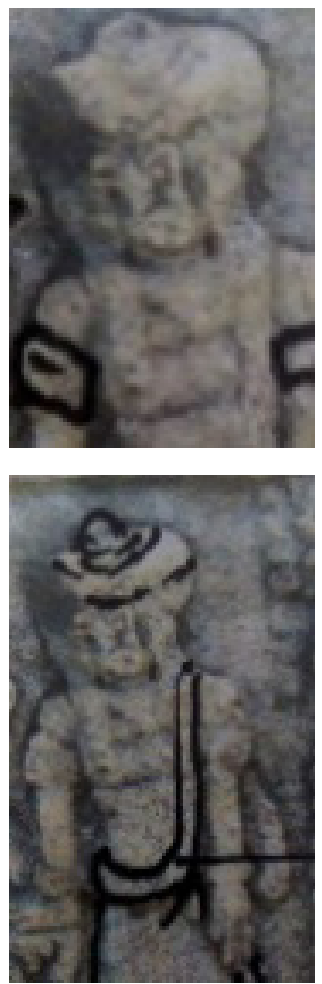

Mengenakan Upawita atau tali kasta, dari bahu kiri melintang di depan dada hingga ke pinggang ${ }^{\text {xviii. }}$

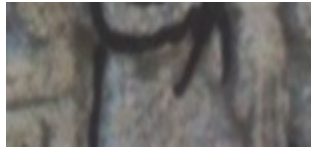

Sabuk dipakai untuk mengikat kain pada pinggang.

permainan tata cara berbusana kain Jawa yang dilipat-lipat pada bagian tengah kain membujur ke atas. Apabila tersibak akan terlihat seperti bentuk kipas, identik dengan gaya pakaian di Keraton Jawa. Gaya busana semacam ini, menurut Ciptandi, Sachari, \& Haldani (2016, hlm. 269), adalah bukti adanya
Tabel 6. Analisis Rupabheda Relief Detail Begawan Tambapetra

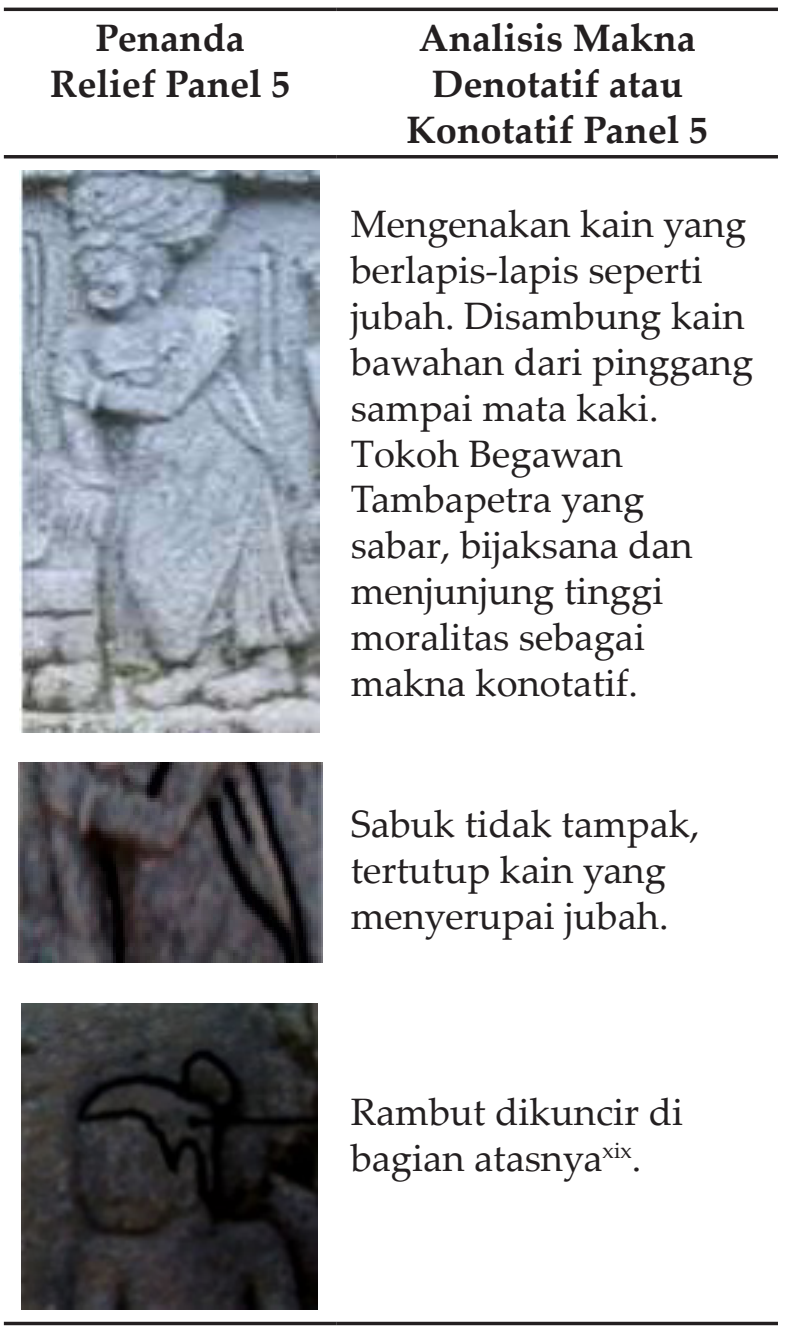

Tabel 7. Analisis Rupabheda Relief mbok emban

\begin{tabular}{cl}
\hline $\begin{array}{c}\text { Penanda } \\
\text { Relief Panel 6 }\end{array}$ & $\begin{array}{c}\text { Analisis Makna Denotatif } \\
\text { atau Konotatif Panel 6 }\end{array}$ \\
\hline & $\begin{array}{l}\text { Salah satu dari pelayan Sri } \\
\text { Tanjung yang setia, mene- } \\
\text { mani dalam suka dan duka. } \\
\text { Pelayan wanita hanya men- } \\
\text { genakan kain dari ping- } \\
\text { gang sampai ke mata kaki. } \\
\text { Bagian dada tidak ditutup } \\
\text { kemben }\end{array}$ \\
& $\begin{array}{l}\text { Sabik digunakan untuk } \\
\text { mengikat kain di pinggang }\end{array}$ \\
\hline
\end{tabular}


Tabel 8. Analisis Rupabheda Relief Punakawan

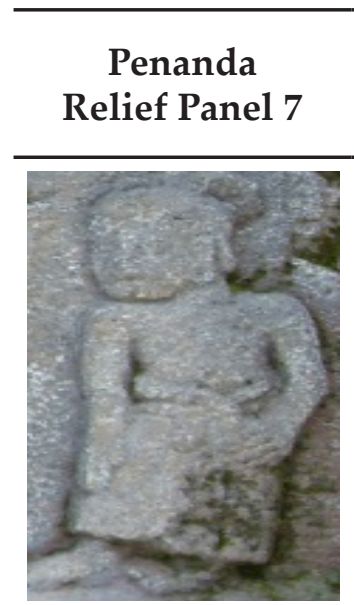

\section{Analisis Makna \\ Denotatif atau \\ Konotatif Panel 7}

Salah satu dari dua punakawan Sidapaksa yang setia, jujur dan rela berkorban untuk majikannya.

Kepolosan dan keluguan karakter menjadi makna konotatif.

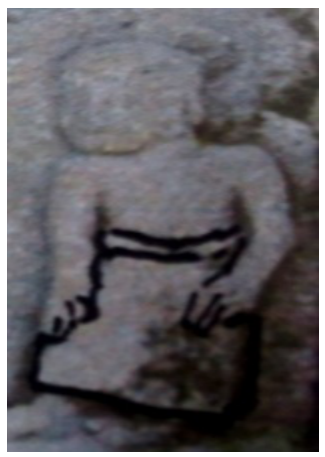

Pelayan Sidapaksa memakai kain sarung yang hanya dibelitkan di pinggang, dan diikat dengan sabuk.

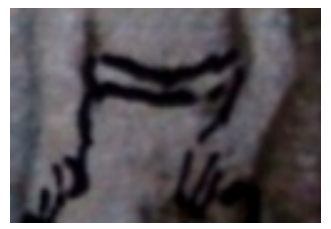

Sabuk digunakan mengikat kain di pinggang.

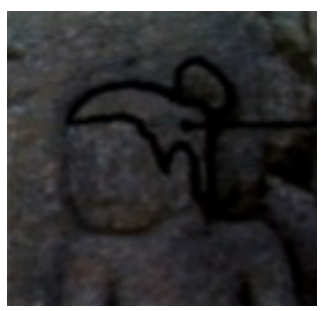

Pelayan yang selalu dekat Sri Tanjung umumnya dengan rambut digelung ${ }^{x x}$.

penyesuaian (akulturasi) dan representasi pemahaman masyarakat kala itu terhadap konsep kosmologi dan estetika.

Berdasarkan penanda atau Rupabheda relief Begawan Tambapetra pada Tabel 6, tampak gestur ibu jari tangan yang keluar, dan keempat jari tangan yang dilipat menunjukkan tata cara budaya Jawa dalam berkomunikasi. Ini adalah posisi memberi wejangan ke orang lain tanpa harus menunjuk-nunjukkan tangan ke tubuh (apalagi wajah) orang lain.
Sedangkan relief Punakawan pada Tabel 7 dan Tabel 8, lebih menggambarkan kedudukannya sebagai pelayan yang setia. Interpretasi ini didasarkan pada kenampakkan gerak tubuh yang memberi karakter suka dagelan (bercanda). Ciri khas tersebut juga sebagai bentuk ekspresi kesetiaan pelayan yang menikmati kesehariannya dalam bekerja. Kepolosan wajah yang tidak suka berdandan juga menunjukkan kebersahajaan hidup pekerja Jawa rendahan.

Bagaimana korelasi cerita Panji dengan cerita Sri Tanjung? Dari penelitian ini diketemukan bahwa banyak ciri yang menandai bahwa Kisah Panji sebenarnya adalah narasi khas Jawa zaman Majapahit. Berarti bahwa cerita tersebut bukan saduran atau petikan dari epos-epos India yang telah dikenal sebelumnya. Apabila diuraikan satu persatu, butir penanda karya kejawaan pada cerita Panji antara lain:

a.Tokoh-tokoh merupakan ciptaan baru, bukan kisah para ksatria dari epos India. Tokoh-tokoh ksatria itu bukannya ksatriaksatria India yang bergerak di alam Jawa, melainkan ksatria dari keraton-keraton Jawa sendiri yang berperanan dalam kisah Panji. Adapun di dalam cerita Sri Tanjung, tokoh-tokohnya menggunakan nama lokal, yaitu: Sidapaksa, Sri Tanjung, Sulakrama, dan Tambapetra.

b.Biasanya cerita Panji memiliki alur khas, yaitu diawali dengan kisah romantika sepasang kekasih, yang kemudian dipisahkan oleh suatu perkara, hingga kemudian dipertemukan kembali dan berakhir dengan hidup bahagia. Berbeda 
dengan cerita Sri Tanjung, yang diawali dengan pertemuan Sri Tanjung dengan Sidapaksa, kemudian terjadi konflik dan berpisah. Pada akhir dari cerita tersebut, Sidapaksa dipertemukan kembali dengan Sri Tanjung.

Dari isi cerita dan gaya pengekspresian wujud tokoh-tokohnya, pada relief Sri Tanjung, terdapat berbagai simbol yang memperlihatkan pembebasan karakter dari paham Ramayana dan Mahabharata. Sri Tanjung memiliki makna yang menyiratkan kesetiaan Sri Tanjung terhadap suaminya, sebagai wujud bakti kaum perempuan Jawa. Sidapaksa sebagai pekerja rendahan yang rendah hati dan bertanggungjawab pada tugasnya, tetapi ketika dikhianati Ia tanpa kompromi memutus kedengkian yang mengusik ketentraman hidupnya.

\section{PENUTUP}

Visualisasi tokoh dalam cerita Sri Tanjung, menunjukkan bahwa penanda aksesoris yang dikenakan merupakan ikon budaya yang berasal dari Jawa Pertengahan. Identitas batik, cara berpakaian kemben, kain yang di-wiru, dan ekpresi permainan jempol tangan menunjukkan karakter kearifan lokal budaya Jawa. Aspek feminis, maskulin, tamak, dan suka banyolan berhasil diungkap dalam hasil analisis Rupabheda relief. Meskipun figur relief dibuat pipih dan terdistorsi mendekati bentuk abstrak dekoratif wayang kulit, namun tetap terbaca artikulasi visual penanda dan tetap bisa ditafsirkan maknanya lebih lanjut.
Di samping itu, berdasarkan isi cerita dapat disimpulkan bahwa cerita Sri Tanjung berasal dari mantra Jawa. Hal tersebut bisa dijadikan indikator, bahwa situasi sosial budaya pada masa kerajaan Kediri hingga Majapahit akhir, kendati masih dibayangbayangi seni budaya India, tetapi lebih terbuka untuk mengedepankan budaya lokal Jawa Pertengahan. Visualisasi relief cerita Sri Tanjung telah menyamarkan ikon budaya Jawa Pertengahan ke dalam relief arca Hindu. Relief ini juga secara sekaligus telah memasukan narasi cerita lokal yang berbeda dengan cerita Mahabharata-Ramayana. Sri Tanjung merupakan ekspresi keinginan keluar dari pakem simbol-simbol seni India yang realistik-naturalis ke dalam relief abstrak dekoratif.

\section{Daftar Pustaka}

Adnyana, I. W., Negara, I. N. S., Sari, D. I. D., \& Udayana, A. B. (2017). Exploring Yeh Pulu Relief (An iconography approach). Mudra: Jurnal Seni Budaya, 32(3), 277-282.

Adnyana, I. W., Remawa, A. A. R., \& Sari, N. L. D. I. D. (2018). Multinarasi Relief Yeh Pulu Basis Penciptaan Seni Lukis Kontemporer. Mudra: Jurnal Seni Budaya, 33(2), 249-255.

Atmodjo, M. M. S. K. (1978). Wanita Padmanagara. Majalah Arkeologi, 2(2), 3-15.

Bagus, Loren. 2005. Kamus Filsafat. Jakarta: Gramedia Pustaka Utama.

Ciptandi, F., Sachari, A., \& Haldani, A. (2016). Fungsi dan nilai pada kain batik tulis 
Gedhog khas masyarakat di Kecamatan Kerek, Kabupaten Tuban, Jawa Timur. Panggung, 26(3), 261-271.

Degroot, V. (2006). The Archaeological Remains Of Ratu Boko: From Sri Lankan Buddhism to Hinduism. Indonesia and the Malay World, 34(98), 55-74.

Degroot, V. (2015). Following The Cap-Figure In Majapahit Temple Reliefs: A New Look at The Religious Function of East Javanese Temples, 14 and 15 Centuries. Asian Studies Review, 39(3), 534-535. https://doi.org/10.1080/10357823.2015.1 006309

Endraswara, S. (2013). Seksologi Jawa. Jakarta: Wedatama Widya Sastra.

Gandhi, I. (2010). Understanding Indian art forms: Introduction to Visual Arts (2nd ed.). New Delhi: Indira Gandhi National Open University.

Geertz, C. (2000). The interpretation of cultures: Selecterd essays. New York: Basic Books.

Harto, D. B. (2014). Analisis Bahasa Rupa Relief Jataka Candi Borobudur. In Diversity of Tradition as Cultural Heritage (pp. 25-42). Jakarta: Universitas Trisakti.

Holt, Claire Holt. Diterjemahkan oleh R. M. Soedarsono. 2000. Seni di Indonesia: Kontinyuitas dan Perubahan. Yogyakarta: Institut Seni Indonesia.

Holt, C. (2000). Melacak Jejak Perkembangan Seni Di Indonesia. Bandung: arti.line.

Indradjaja, A. (2017). Penggambaran Ideal Perempuan Jawa pada Masa HinduBuddha: Refleksi pada Arca-Arca Perempuan. Purbawidya: Jurnal Penelitian Dan Pengembangan Arkeologi, 6(7), 105-116.

Istanto, R. (2018). Estetika Hindu pada Perwujudan Ornamen Candi di Jawa. Imaji, 16(2), 155-161.

Istanto, R., \& Syafii. (2017). Ragam Hias Pohon Hayat Prambanan. Imaji, 11(1), 19-28.

Iswati. (2016). Kajian Estetika dan Makna Simbolik Ornamen Di Komplek Makam Sunan Sendang Desa Sendangduwur, Paciran, Lamongan. Universitas Negeri Semarang.

Jamharil. (2010). Penggambaran Relief Sudhamala di Candi Tegawangi
Ditinjau Berdasarkan Kaidah Kesenian Sad-Angga. Universitas Indonesia.

Jordaan, R. E. (2006). Why The Sailend ras were Not A Javanese Dynasty. Indonesia And The Malay World, 34(98), 3-22.

Jordaan, R. E. (2009). Memuji Prambanan. Jakarta: Yayasan Obor Indonesia.

Julianto, I. N. L., Jodog, I. M., \& Santosa, I. (2016). Nilai interaksi simbol tradisi dalam wujud pelinggih pada ruang publik. Panggung, 26(1), 24-34.

Kieven, Lidya. 2014. “Simbolisme Cerita Panji dalam Relief-relief di Candi Zaman Majapahit dan Nilainya pada Masa Kini". Seminar Naskah Panji. Jakarta: Perpustakaan Nasional Republik Indonesia.

Munandar, A. (2018). Antrala Arkeologi Hindu-Budha. Jakarta: Wedatama Widya Sastra.

Munandar, A. A. (1999). Berbagai Bentuk Ragam Hias pada Bangunan HinduBudha dan Awal Masuknya Islam di Jawa. Wacana, 1(1), 49-69.

Mustaqin, K. (2017). The contribution of cultural art in creating Liong ornament on the roof Tay Kak Sie temple in Semarang Central Java. Panggung, 27(4), 372-379.

Nawiroh, Vera. 2014. Semiotika dalam Riset Komunikasi. Bogor: Ghalia Indonesia.

Panofsky, E. (1971). Studies in Iconology. Colorado: Icon.

Poerbatjaraka dalam Sedyawati, Edi. 2001. Sastra Jawa Suatu Tinjauan Umum. Jakarta: Balai Pustaka.

Prasetya, H. B. (2016). Rama sebagai penjaga kehidupan dalam relief ramayana Prambanan. Kawistara, 3(22), 225-324.

Prawira, N. G. (2001). Penemuan Jatidiri dan Puncak Perkembangan Seni Rupa Indonesia-Lama pada Zaman Singhasari dan Majapahit di Jawa Timur. Wacana Seni Rupa, 3(6).

Raffles, T. S. (1817). The history of Java (Vol. 1). London: John Murray.

Royo-iyer, A. L. Y. (1991). Dance Images of Ancient Indonesian Temples (Hindu/ Buddhist Period): The Dance Reliefs of Borobudur. Indonesia Circle. School of Oriental \& African Studies. 
Newsletter, 20(56), 3-23. https://doi. org/10.1080/03062849108729768

Rustarmadi. 2014. "Ragam Hias pada Pendapa Teras Candi Penataran di Blitar". Seminar Naskah Panji. Jakarta: Perpustakaan Nasional Republik Indonesia.

Santiko, Hariani. 2014. “Candi Penataran: Candi Kerajaan Masa Majapahit". Seminar Naskah Panji. Jakarta: Perpustakaan Nasional Republik Indonesia.

Sari, S. M., \& Pramono, R. S. (2008). Kajian Ikonografis Ornamen pada Interior Klenteng Sanggar Agung Surabaya. Jurnal Seni Dimensi Interior, 6(2), 7384.

Sedyawati, E. (1981). Pertumbuhan Seni Pertunjukkan. Jakarta: Sinar Harapan.

Sediawati, Edi Sedyawati. 2000. Pertumbuhan Seni Pertunjukan. Jakarta: Sinar Harapan. Cetakan kedua.

Sharma, R. K. (2016). Shadanga-The Limbs of Art. International Journal of All Research Education and Scientific Methods, 4(5), 34-38.

Sianipar, K., Gunardi, G., Widyonugrahanto., \& Rustiyanti, S. (2015). Makna seni ukiran Gorga pada rumah adat batak. Panggung, 25(3), 227-235.

Sumardjo, J. (2000). Filsafat Seni. Bandung: ITB.

Sunaryo. (2009). Ornamen Nusantara: Kajian Khusus tentang Ornamen Indonesia. Semarang: Dahara Prize.

Supriatna. (2014). Komunikasi visual pada acuk kuda renggong. Panggung, 24(3), 275-284.

Susetyo, S. (2002). Pandangan Masyarakat Jawa tentang Perkawinan pada Jawa Kuna Hingga Kini (Berdasarkan karya satra dan relief). Amerta, 22, 84-98.

Syafii, \& Rohidi, T. R. (1987). Ornamen Ukir. Semarang: IKIP Semarang Press.

Totton, M. (2003). Narrating Animals on The Screen of The World. The Art Bulletin, 85(1), 6-24. https://doi.org/10.1080/000 43079.2003.10787059

Totton, M. (2011). The Pangolin: A Multivalent Memento in Indonesian Art. Indonesia And The Malay World, 39(113), 7-28. https://doi.org/10.1080/13639811.2011.5 47727

Wirjosuparto, S. (1956). Sedjarah Seni Artja India. Jakarta: Kalimosodo.

\section{Website/laman}

Anyaman Pandan, retrieved August 10, 2019, from: https://gandsakri.wordpress. com/2010/06/16/anyaman-pandan/

Mode Kain Pria, retrieved August 10, 2019, from: https://luk.staff.ugm.ac.id/itd/ Pers/02.html

Sensualitas Wanita Jawa abad ke 18, retrieved August 10, 2019, from: https://www.kaskus.co.id/ thread/53e3193f96bde6d5058b456f/ sensualitas-wanita-jawa-abad-ke-18/

Model Kain Pria: Pangerang Madura, retrieved August 10, 2019, from: https://commons.wikimedia.org/wiki/ File:COLLECTIE_TROPENMUSEUM_ Pangerang_(prins)_van_Madura_ TMnr_3728-224.jpg

Buah Kepel: Taman Sari Jogja: Wahana Air Keraton Dengan Nuansa Magis, retrieved August 10, 2019, from: https://dwijayantiw.word press. com/2015/07/10/taman-sari-jogja/

Ilustrasi Prajurit Keraton Kasultanan Yogyakarta (1864), retrieved August 10, 2019, from: http://tempodoeloe. suarajogja.net/

Stilasi Mahameru Rumah Jawa, retrieved August 10, 2019, from: https:// id.pinterest.com/sigitpriwibowo/nedindie/

Dewa Baruna (Varuna) dewa Laut dan Air, retrieved August 10, 2019, from: http:// www.mantrahindu.com/dewa-barunavaruna-dewa-laut-dan-air/

\section{Catatan Belakang}

i. Istilah abstraksi atau dalam bahasa Inggris abstraction bisa diartikan memisahkan sebagian dari suatu keseluruhan. Abstraksi merupakan suatu proses yang ditempuh pikiran untuk sampai pada konsep yang bersifat universal. Proses ini berangkat dari pengetahuan mengenai objek individual yang bersifat spasio 
temporal (ruang dan waktu). Pikiran melepas sifat individual dari objek dan membentuk konsep universal. Loren Bagus, 2005, Kamus Filsafat, Jakarta: Gramedia Pustaka Utama, p. 6-7.

ii. Lidya Kieven, 2014, "Simbolisme Cerita Panji dalam Relief-relief di Candi Zaman Majapahit dan Nilainya pada Masa Kini”, Seminar Naskah Panji, Jakarta: Perpustakaan Nasional Republik Indonesia, p. 4.

iii. Porbatjaraka dalam Edi Sedyawati, 2001, Sastra Jawa Suatu Tinjauan Umum, Jakarta: Balai Pustaka, p. 4.

iv. Rustarmadi, 2014, "Ragam Hias Pada Pendapa Teras Candi Penataran Di Blitar", Seminar Naskah Panji, Jakarta: Perpustakaan Nasional Republik Indonesia, p.175.

v. Lidya Kieven, Loc. Cit.

vi. Ibid. p. 7.

vii. Rustarmadi, Loc. Cit.

viii. Vera, Nawiroh, 2014, Semiotika dalam Riset Komunikasi, Bogor: Ghalia Indonesia, p. 28.

ix. Lidya Kieven, Loc. Cit.

x. Prihani Pratiwi, Op. Cit., p. 63.

xi. Ibid.

xii. Hariani Santiko, 2014, "Candi Penataran:

Candi Kerajaan Masa Majapahit", Seminar Naskah Panji, Jakarta: Perpustakaan Nasional Republik Indonesia, p. 21.

xiii. Claire Holt, Diterjemahkan oleh R. M. Soedarsono, 2000, Seni di Indonesia: Kontinyuitas dan Perubahan, Yogyakarta: Institut Seni Indonesia, p. 46.

xiv. Prihani Pratiwi, Op. Cit., p. 75.

xv. Rustarmadi, Op.Cit., p. 175.

xvi. Ibid.

xvii. https://id.wikipedia.org/wiki/Kelat_bahu

xviii. https://id.m.wikipedia.org/wiki/Upawita xix. Rustarmadi. Loc. Cit.

$\mathrm{xx}$. Ibid.

xxi. Ibid. 